\title{
China-ASEAN Free Trade Area Development Status Quo and Trade Effect Analysis
}

\author{
Changze Wang \\ Institute of Economy, Jinan University, Guangzhou, China \\ Email: wangctik@163.com
}

How to cite this paper: Wang, C.Z. (2018) China-ASEAN Free Trade Area Development Status Quo and Trade Effect Analysis. Modern Economy, 9, 719-733.

https://doi.org/10.4236/me.2018.94047

Received: March 5, 2018

Accepted: April 21, 2018

Published: April 24, 2018

Copyright $\odot 2018$ by author and Scientific Research Publishing Inc. This work is licensed under the Creative Commons Attribution International License (CC BY 4.0).

http://creativecommons.org/licenses/by/4.0/

\section{cc) (i) Open Access}

\begin{abstract}
From the starting of CAFTA in 2002, the economic and trade contact between China and ASEAN has become increasingly frequent. Both sides have achieved good development, which actively promoted the development of free trade area. First of all, this paper introduces the current situation of trade of China-ASEAN Free Trade Area, including the general situation of trade of China and ASEAN, the balance trade of China and ASEAN and key trade industry between China and ASEAN. And secondly, this paper analyzes the Trade Creation Effects through the share of Chinese exports to ASEAN in Chinese total export volume, which finds that the proportion of Chinese exports to ASEAN has increased steadily and that generated a certain trade creation effects. And also the paper analyzes the outside trade diversion effect through the share of Chinese imports and exports with ASEAN in China's total trades, which shows that China has also created a certain extent Trade Diversion Effect. What's more, this paper selects the data from China, ASEAN countries and China's important trade partners, and establishes the panel data from 2003 to 2016. It carries on an empirical analysis on China's trade creation effect by using the econometric model. Finally, this article puts forward some promoting development countermeasures of China-ASEAN free trade area by the obstacles in the developing process of CAFTA at present, according to the study results.
\end{abstract}

\section{Keywords}

CAFCA, Trade Creation Effect, Trade Diversion Effect

\section{Introduction}

\subsection{Background and Significance of the Study}

In 2002, China and the 10 member states of ASEAN started to form a China-ASEAN 
free trade zone and signed the Framework Agreement on Comprehensive Economic Cooperation between China and ASEAN, marking the start of the China-ASEAN Free Trade Area. At the same time, it means that China is now using Open attitude, actively participates in international trade and promotes economic development in the Asia Pacific region. Since ASEAN countries are located in Southeast Asia, they have certain similarities in terms of language, culture and ideology, which provide a good foundation for the development of the China-ASEAN Free Trade Area. Although the China-ASEAN Free Trade Area has enjoyed rapid development since the founding of the CAFTA was formally established, the economy of all countries has enjoyed rapid development during this short span of more than 10 years. The bilateral trade volume has doubled and the cooperation and exchange have been deepened, which has laid a solid foundation for the future development.

Standing on the stage of the New Era, looking at the development of China's economy and deepening the reform and facing the new normalcy of the economy, China faces many new choices. At the same time, we also must see the potential challenges and hidden dangers are also very huge. In order to not be in a passive position in the new round of competition, China must have sufficient right to speak and to formulate rules in order to have ample ownership and intention to express itself in the new round of international economic development so as to provide the economy new take-off of China to lay a solid foundation. Then, in Asia, it is necessary for China to use its huge regional development platform such as the China-ASEAN Free Trade Area to enhance its international influence and international competitiveness.

On the New Year's Day in 2010, the China-ASEAN Free Trade Area was officially established. Since then bilateral trade has developed rapidly and bilateral economic and trade cooperation has been deepened. Therefore, it is of great practical significance to study the trade effect between China and ASEAN. First of all, due to the short time it takes to build a free trade zone and the relatively few theoretical studies on the trade effects between China and ASEAN, theoretical studies can be expanded. Second, we can analyze the competitiveness of China and ASEAN in a targeted manner, analyze their respective advantages in competitive advantage and trade complementarity in specific trade processes, and promote the continuous development of the free trade area. Finally, through the trade effect analysis and the current status of trade, some relevant recommendations are put forward to promote the China-ASEAN Free Trade Area of the future development.

\subsection{Related Research Literature Review}

Since the establishment of the China-ASEAN Free Trade Area in 2002, many scholars have studied China-ASEAN Free Trade Area from different perspectives. Some studies are conducted from the perspective of trade similarity, complementarity, and competitiveness between China and ASEAN. Such as: Zhou 
Yan [1] believes that trade between China and ASEAN is highly competitive, especially labor-intensive industries, but there is a certain gap between the two sides in the development of the tertiary industry. Therefore, in this regard, Complementarity can bring economic and trade benefits to both parties. Jiang Shuzhu and Zhang Xukun (2003) established the China-ASEAN Free Trade Area by establishing a trade gravity model, which promoted the development of bilateral trade and increased the level of intra-industry trade. By comparing the advantage index with the export similarity index, it shows that there is competition between China and ASEAN in intensive use of labor products. In addition, complementarity will also increase the trade volume between the two sides and promote the free trade zone to keep coming; Shi Zhiyu [2] concludes that by analyzing the bilateral trade relations between China and ASEAN, China and ASEAN have certain complementarities in some aspects, and this The trend will become more and more intense, and the establishment of a free trade zone will bring huge market space to both companies, which will continue to promote the development of bilateral trade.

Some experts and scholars set up economic models to empirically analyze the trade effects of China-ASEAN Free Trade Area. For example, Roberts [3] collected trade data of China and ASEAN countries before and after the start of the free trade zone, established a corresponding econometric model, and analyzed the trade transfer and trade creation effects between China-ASEAN Free Trade Area member states and between China and major trading nations in China. The conclusions prove that China and ASEAN are closer in terms of per capita income and demand, so the amount of trade between them is also greater; Chen Hanlin, Tu Yan [4] through the development of bilateral trade between China and ASEAN Introduced and established a trade gravity model, from the perspective of China, they analyzed the static effects of the China-ASEAN Free Trade Area. The conclusions proved that China's creative effects were smaller than the trade diversion effect, and the difference between the two effects was also constant over time. Park [5] established a related econometric model by introducing the theory of Customs Union and other factors, analyzed the factors of tariff structure and trade type before and after the establishment of China-ASEAN Free Trade Area, and pointed out the establishment of China-ASEAN Free Trade Area can promote trade creation effects among member states, and at the same time, they also thought that non-economic factors can increased the efficiency of economic development of the FTA.

Some experts and scholars stand at the perspective of one or more industries and analyze the bilateral trade situation of the industry to illustrate the trade effect of the establishment of the China-ASEAN Free Trade Area. Such as: Chen Lei, Qu Wenqiao [6] through the study of the world's major countries and regions in the mechanical and electrical industry trade data, established a relevant model to prove that the successful construction of China-ASEAN free trade zone, brought the trade creation effects and trade diversion effects to the elec- 
tromechanical industry in the free trade zone member states.

\subsection{Research Framework, Methods, Innovations and Shortcomings of the Thesis}

\subsubsection{Thesis Research Framework}

The text of this article is divided into four parts; the specific content is as follows.

The first part is the introduction. This chapter mainly elaborated the background and significance of the topic of the thesis. It also briefly described the articles of the China-ASEAN Free Trade Area construction from different perspectives of the study and introduced the trade effect of the free trade zone on China and ASEAN, the research status, research methods and innovations of this paper.

The second part is an overview of the development status of China-ASEAN Free Trade Area. This part introduced China's trade situation with ASEAN, including the changes in China's overall import and export trade volume with ASEAN, the changes in the overall trade balance between China and ASEAN, and the reasons for the trade between China and ASEAN's major trade industries.

The third part is the key part of this paper. This part uses the gravitational model to establish panel data from ASEAN countries and major 10 trading countries in China from 2003 to 2016, and whether trade creation effects have occurred before and after the completion of the free trade area Empirical analysis. This part first analyzes the trade effects of the China-ASEAN Free Trade Area using data analysis and comparison methods, including the trade creation effects and trade transfer effects. Secondly, it constructs relevant econometric models through the collected data and analyzes China-ASEAN free trade. The establishment of the district tests the trade creation effects.

The fourth part is to address the issue of restricting the development of the China-ASEAN Free Trade Area, and to put forward some policy recommendations, including accelerating the upgrading of the industrial structure of the two sides, expanding the trade volume between the two sides, and helping ASEAN's economic development level lag behind the development of the country.

\subsubsection{Thesis Research Method}

The research methods used in this paper mainly include the following.

First, a descriptive analysis method. Through the statistics on the import and export volume of China, ASEAN and major trading countries, statistical methods such as the proportion of trade volume and growth rate were used to describe China's trade creation effects and trade transfer effects.

Second, empirical analysis methods. Through the statistics of China-ASEAN and the statistics of China's major trading countries including imports, exports, GDP, and other data, we use measurement methods to establish panel data for 2003-2016, and conduct empirical analysis on trade creation. 


\subsubsection{The Innovation of the Thesis}

First, a descriptive analysis method is used to analyze China's trade creation effects and trade transfer effects. Not only the data comparison of the total import and export volume are carried out, but also the trade data of the major industries are selected for descriptive analysis.

Second, data from 2003 to 2016 in China and ASEAN countries as well as China's 10 major trading countries have been selected to be more accurate in analyzing the trade creation effects of China-ASEAN Free Trade Area.

\section{The Trade Status of China-ASEAN Free Trade Area}

\subsection{The Overall Development of Trade between China and ASEAN}

\subsubsection{Overview of Bilateral Trade between China and ASEAN}

In 2002, the trade volume between China and ASEAN totaled 54.8 billion US dollars. ASEAN ranked fifth in China's trading partners and China ranked third in the trading partners of ASEAN. In 2004, the bilateral trade volume between China and ASEAN was 105.9 billion US dollars. It is estimated that the goal of 100 billion US dollars realized in 2005 will be realized one year ahead of schedule. In 2007, the bilateral trade volume reached 202.5 billion US dollars, achieving the estimated target of 200 billion US dollars in 2010, three years ahead of schedule. By 2017, the bilateral trade volume between China and ASEAN has reached 514.8 billion US dollars, up 13.8\% over the same period of last year, 9.4 times the bilateral trade volume in 2002, an average annual growth rate of $20 \%$, and ASEAN ranked to the third trading partner ranking in China rising from fifth place, China ranked to the top from the third in the ASEAN's trading partners. Since the establishment of the China-ASEAN Free Trade Area, the bilateral trade volume has witnessed rapid growth in the past 10 years or so. Substantial progress has been made in all aspects of cooperation. Trade has become increasingly frequent and trade between China and ASEAN has been increased. The rapid and sound development of the cooperation has achieved remarkable results. The specific data are shown in Figure 1.

In 2014, the total bilateral trade between China and Laos was 3.61 billion US dollars, an increase of $32.2 \%$ over 2013. Among them, China's import to Laos was 1.78 billion US dollars, up by $76.2 \%$ over the previous year, with an export volume of 18.4 billion US dollars, an increase of $8.3 \%$ over 2013. In 2014, the total trade volume between China and Myanmar was 24.97 billion US dollars, up $144.8 \%$ over 2013. In 2016, the total trade volume between China and Vietnam was 98.27 billion US dollars, achieved continuous growth for 14 years. In 2017, Vietnam has become China's first largest trading partner in the ASEAN region. As can be seen from Table 1, the trade volume between China and Vietnam in 2003 was only 4.64 billion US dollars. By 2016, the volume of trade between the two countries increased rapidly, increasing 20 times as much as that of the FTA and $30 \%$ of the year. The average growth rate is also higher than the average annual growth rate of $18 \%$ of China's foreign trade in more than a decade. 


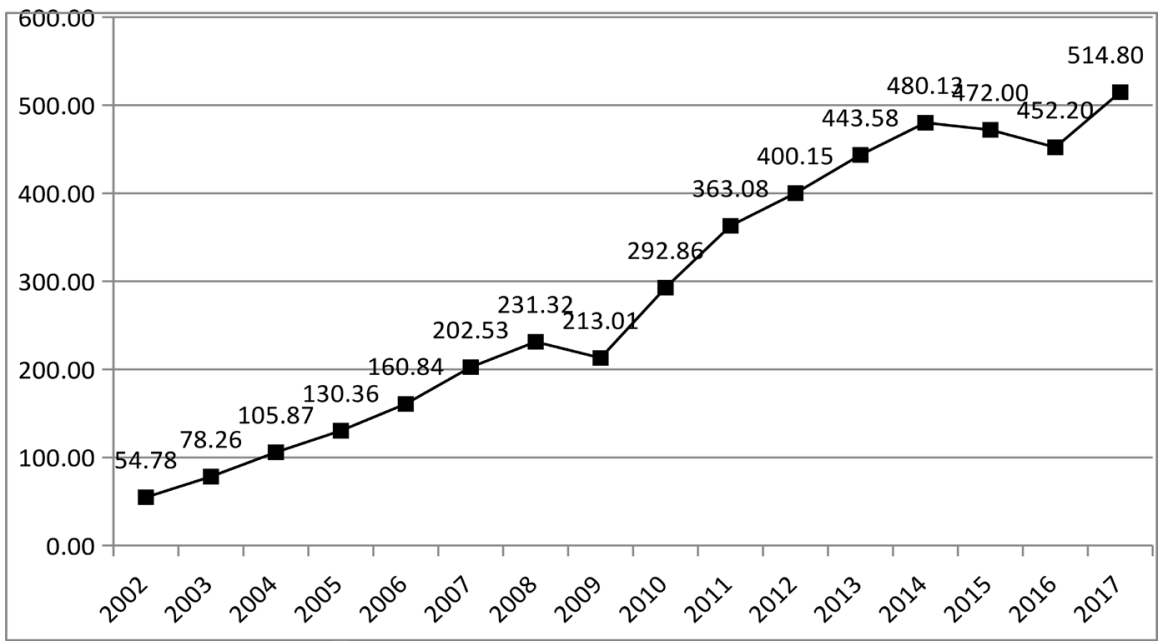

(Source: UN COMTRADE data).

Figure 1. The trade volume chart of China and ASEAN each year (unit: billion dollars).

Table 1. The trade volume of China and ASEAN's members each year (unit: billion dollars).

\begin{tabular}{ccccccccccc}
\hline Country & 2003 & 2005 & 2007 & 2009 & 2011 & 2012 & 2013 & 2014 & 2015 & 2016 \\
\hline Malaysia & 20.13 & 30.7 & 46.47 & 51.96 & 90.02 & 94.83 & 106.08 & 102.01 & 97.26 & 86.93 \\
Vietnam & 4.64 & 8.2 & 15.12 & 21.05 & 40.21 & 50.44 & 65.48 & 83.63 & 95.85 & 98.27 \\
Indonesia & 10.23 & 16.79 & 25 & 28.39 & 60.55 & 66.23 & 68.35 & 63.55 & 54.23 & 53.53 \\
Singapore & 19.35 & 33.15 & 47.14 & 47.86 & 63.71 & 62.97 & 75.9 & 79.72 & 79.52 & 70.51 \\
Thailand & 12.65 & 21.81 & 34.64 & 38.19 & 64.73 & 69.75 & 70.64 & 72.62 & 75.46 & 75.72 \\
Philippines & 9.4 & 17.56 & 30.62 & 20.54 & 32.25 & 36.38 & 38.05 & 44.46 & 45.64 & 47.23 \\
Brunei & 0.35 & 0.26 & 0.36 & 0.42 & 1.31 & 1.63 & 1.79 & 1.94 & 1.51 & 0.73 \\
Cambodia & 0.32 & 0.56 & 0.93 & 0.94 & 2.5 & 2.92 & 3.77 & 3.76 & 4.43 & 4.72 \\
Laos & 0.11 & 0.13 & 0.26 & 0.75 & 1.3 & 1.72 & 2.73 & 3.61 & 2.77 & 2.35 \\
Myanmar & 1.08 & 1.21 & 2.08 & 2.9 & 6.5 & 6.97 & 10.2 & 24.97 & 15.1 & 12.29 \\
Total & 78.3 & 130.4 & 203.2 & 213 & 363 & 400.1 & 443.6 & 480.3 & 471.8 & 452.3 \\
\hline
\end{tabular}

\subsubsection{Changes in Trade Balance between China and ASEAN}

Trade balance is the difference between a country's (or region's) total exports and total imports over a given period of time. When the total export volume is larger than the total import volume, we call it the "trade surplus". When the total import volume is larger than the total export volume, we call it the "trade deficit". When the total export volume equals the total import volume, it is called the "trade balance". Table 2 shows the difference between China's import and export trade with ASEAN.

According to the data in Table 2, we draw the annual charts of China-ASEAN bilateral trade balance from 2002 to 2014, as shown in Figure 2. From Figure 2, we can see that from 2000 to 2011, China's trade with ASEAN has been in a deficit range with great volatility. In 2011, China's trade reached a maximum of 
Table 2. Trade balances between China and ASEAN (billions of US dollars).

\begin{tabular}{cccc}
\hline Year & China exports to ASEAN & China imports to ASEAN & Trade balance \\
\hline 2002 & 23.58 & 31.20 & -7.61 \\
2003 & 30.93 & 47.33 & -16.40 \\
2004 & 42.90 & 62.97 & -20.07 \\
2005 & 55.37 & 74.99 & -19.63 \\
2006 & 71.31 & 89.53 & -18.22 \\
2007 & 94.15 & 108.39 & -14.24 \\
2008 & 114.32 & 117.00 & -2.69 \\
2009 & 106.26 & 106.75 & -0.49 \\
2010 & 138.16 & 154.70 & -16.36 \\
2011 & 170.07 & 193.02 & -22.94 \\
2012 & 204.26 & 195.89 & 7.89 \\
2013 & 243.44 & 200.14 & 43.31 \\
2014 & 271.79 & 208.33 & 63.46 \\
2015 & 256.84 & 200.4 & 56.42 \\
2016 & 276.5 & 190.4 & 86.08 \\
\hline
\end{tabular}

Source: UN COMTRADE data.

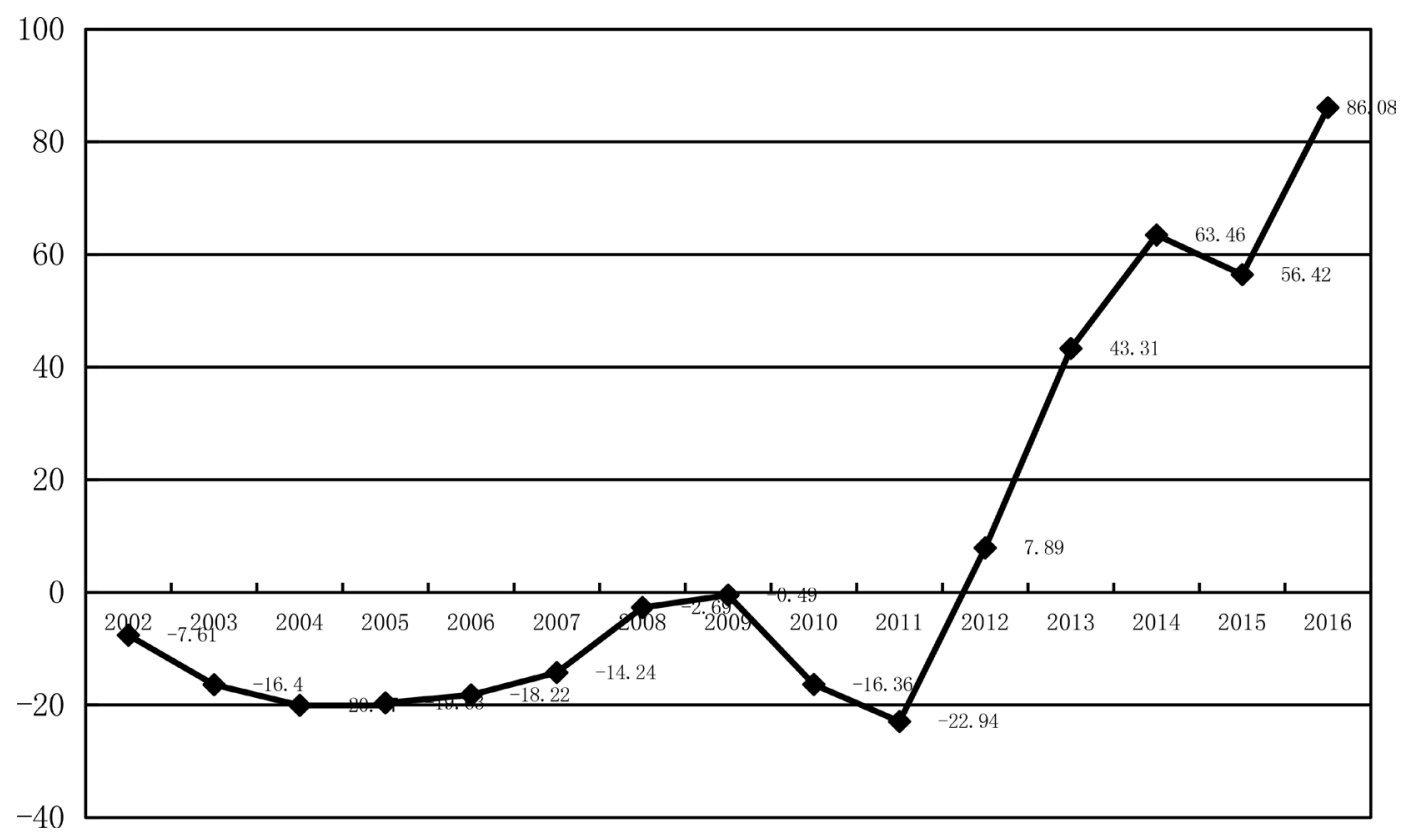

(Source: UN COMTRADE data).

Figure 2. China-ASEAN bilateral trade balance chart for each year.

-22.944 billion US dollars and the minimum was -41.7 million US dollars in 2009. However, with the formal establishment of the China-ASEAN Free Trade Area, the trade deficit has been relatively reduced. In 2012, the trade balance between China and ASEAN was transformed into a trade surplus for the first 
time. This shows that when the China-ASEAN Free Trade Area was completed, China's tariffs on exports to the ASEAN countries dropped significantly, even to zero, expanding China's export market in ASEAN. The second was the global financial crisis that broke out in 2008, bringing bilateral trade in goods. There was a temporary contraction. The impact of the financial crisis in 2010 weakened, the trade in goods crunched by the financial crisis has seen a large number of transactions, and China is subject to a relatively serious financial crisis. Therefore, in order to restore the economy, large-volume export inventories are required At this moment, the China-ASEAN Free Trade Area was just completed and there have been substantial concessions in the policies on the export of commodities in comparison with previous years, so as to promote China's appearance of a trade surplus with ASEAN. In the following years, China and ASEAN continued to expand trade in other fields. China's economy gradually escaped from the impact of the financial crisis and trade gradually strengthened.

\subsection{China and ASEAN Main Products Trade Status Quo}

Since the launch of the China-ASEAN Free Trade Area in 2002, bilateral trade has become increasingly closer and the volume of trade has also been growing rapidly year by year. The major industries involved are: electromechanical products, fossil fuels, animal and vegetable oils, rubber and products, steel And steel products, optical instruments, plastic products and organic chemicals.

The following on the mechanical and electrical products, for example, shows China and ASEAN in the product of trade status quo.

As the main commodity of China-ASEAN trade, mechanical and electrical products play a decisive role in bilateral trade. In 2014, ASEAN has become China's fourth largest export market for electromechanical products and the fifth largest market for imports. Through the previous analysis, we can see that China's main trading partners in ASEAN include: Malaysia, Singapore, Thailand, Indonesia and the Philippines. In order to make the research more targeted, the following is an analysis of the trade in mechanical and electrical products between the major trading nations of China and ASEAN.

As can be seen from Figure 3, compared with the year of 2003, the trade volume of machinery and electronic products between China and the major trading partners of ASEAN increased in varying degrees in 2016. In 2009, due to the impact of the global economic crisis, China's trade volume of imports of mechanical and electrical products from its major trading partners with ASEAN has been reduced. China's trade volume of imports of mechanical and electrical products from Malaysia is much higher than that of China's imports of other mechanical and electrical products from other ASEAN countries. Malaysia is China's leading importer of mechanical and electrical products in ASEAN, followed by Thailand, the Philippines and Singapore. From 2002 to 2016, the average annual growth rate of the trade volume of China's imports of electromechanical products from Indonesia, Malaysia, the Philippines, Singapore and Thailand was $13.86 \%, 23.85 \%, 23.02 \%, 15.03 \%$ and $22.62 \%$ respectively. 

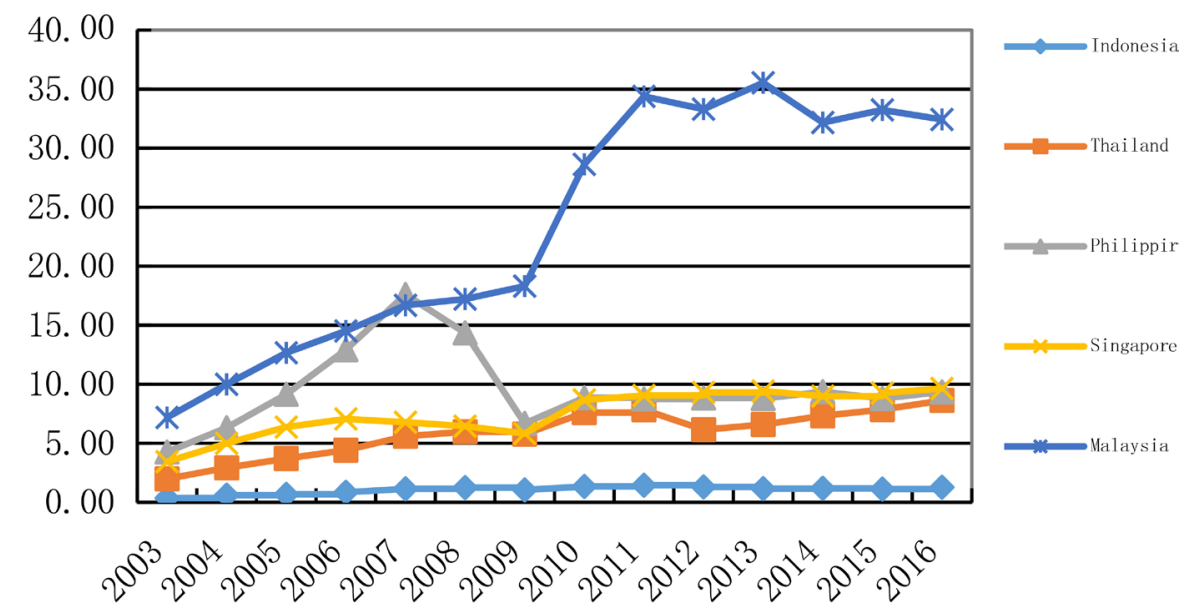

(Source: UN COMTRADE data).

Figure 3. China's import to ASEAN's main trading nation (billions of US dollars).

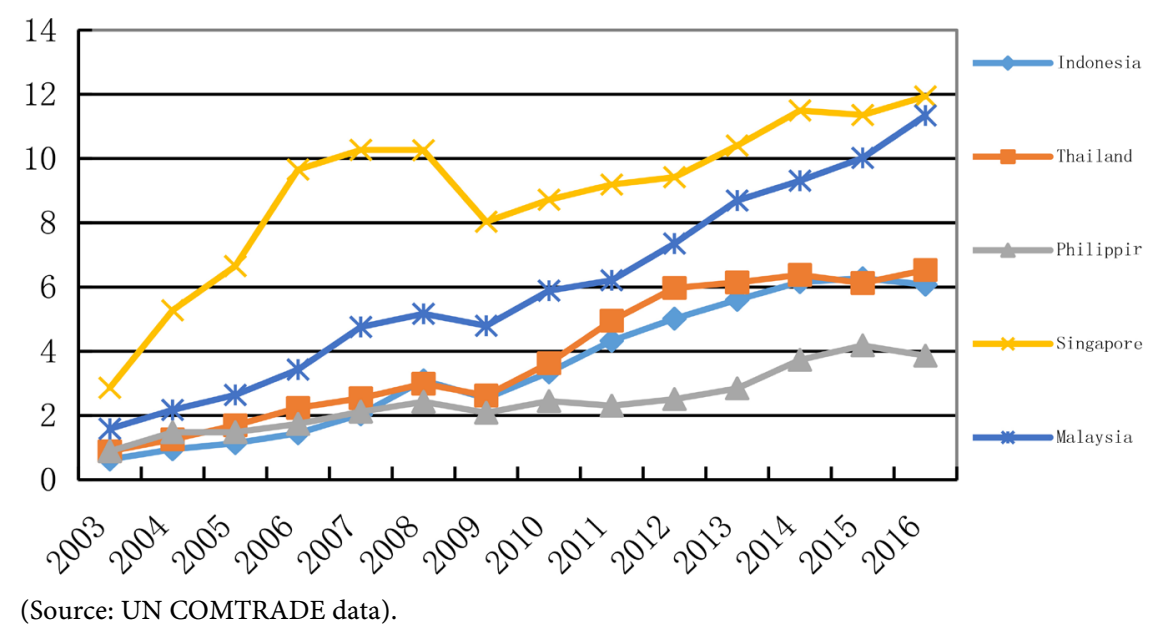

Figure 4. China's exports to ASEAN's major trading partners (billions of US dollars).

Figure 4 shows that in 2016, the trade volume between China and ASEAN's major trading partners increased to varying degrees compared with 2003. In 2009, due to the impact of the global economic crisis, the trade volume of China's electromechanical products from the major trading partners of ASEAN has been reduced. Among them, China's trade volume with Singapore for export of electromechanical products is the highest in ASEAN member countries, followed by Malaysia, Thailand, Indonesia, Philippines. From 2003 to 2016, the average annual growth rates of trade volume of China's exports of electromechanical products from Malaysia, Thailand, Indonesia, the Philippines, and Singapore were $25.61 \%, 22.35 \%, 19.28 \%, 17.65 \%$ and $27.43 \%$ respectively.

The above data show that the changes in the import and export trade volume between China and ASEAN in machinery and electronic products and the trend in the overall trade volume between China and ASEAN are similar, showing different growth rates. In particular, since 2010, China-ASEAN Free Trade After the completion of the district, both sides have substantially reduced tariffs on 
many products (including a large proportion of electromechanical products) and even reduced them to zero. Promote bilateral import and export trade.

\section{China-ASEAN Free Trade Area Trade Effect Analysis}

\subsection{Trade Creation Effects Analysis}

\subsubsection{Analyze Trade Creation Effects through Export Growth Rates}

The formal establishment of a China-ASEAN Free Trade Area in 2010 marks the official launch of the process of China-ASEAN Free Trade Area. Therefore, this section mainly analyzes the growth of China-ASEAN merchandise trade (the export of goods) from 2002 to 2016. Using the data from the Statistical Yearbook of the Statistical Bureau of the People's Republic of China to calculate the annual growth rate of China's exports to the ASEAN, we analyze this The Creative Effect of Trade between China and ASEAN.

It can be seen from Figure 5 that over the past 14 years since the FTA started negotiations, China's export growth rate to the Association of Southeast Asian Nations (ASEAN) has maintained at about 20\%. The trade between the two sides is in good condition. The trade performance is positive except for in 2009's the financial crisis and in 2015's the global economic downturn. Before the start of the FTA and the outbreak of the financial crisis, the growth rate of China's exports to ASEAN rose steadily at a relatively high level with an average annual growth rate of $30 \%$ or so, especially at a rate of $40 \%$ in 2004 . This is because during this period, the process of China-ASEAN cooperation has officially started. In 2004, the "Agreement on Goods in Goods" was formally put into effect and the "early harvest" plan was implemented. China began to slash the tariff rate with all ASEAN countries. This has led to China The trade with ASEAN increased China's exports to ASEAN and boosted the development of China's foreign trade. This shows that the establishment of the China-ASEAN Free

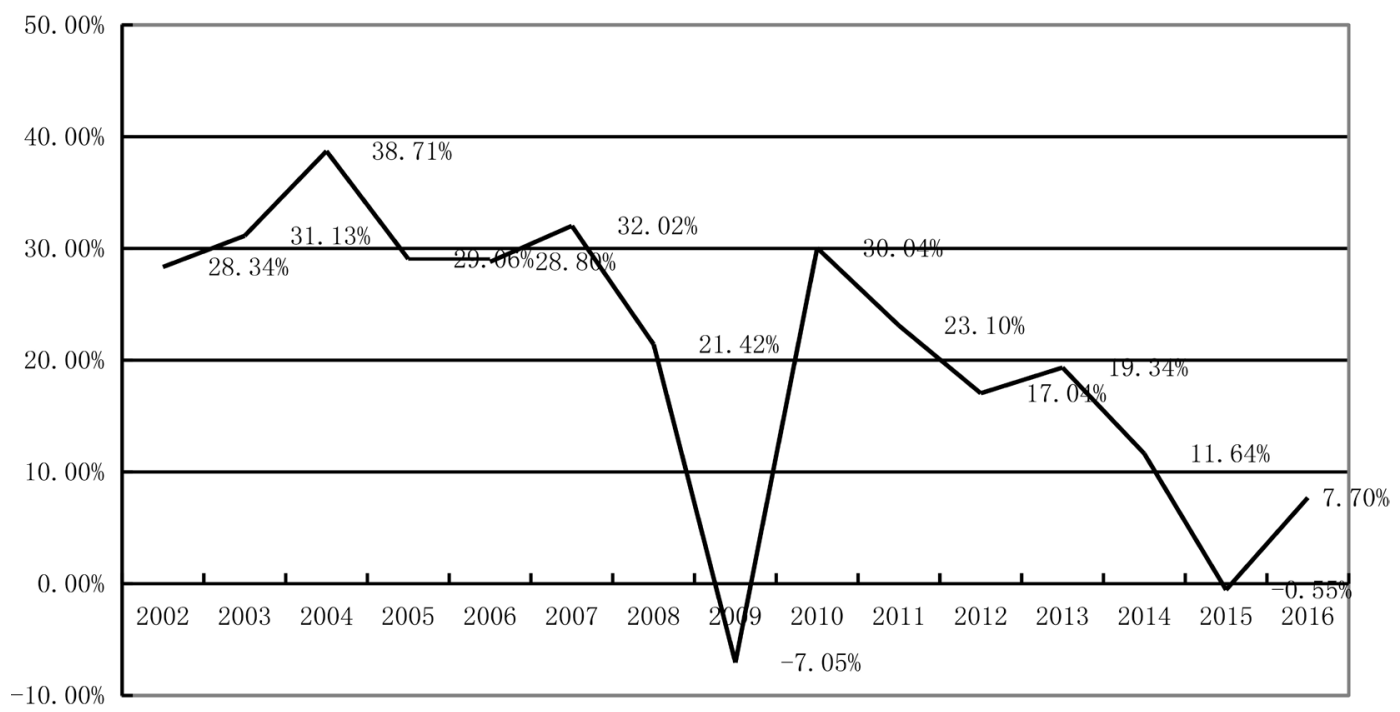

(Source: Statistical Yearbook of the Statistical Bureau of the People's Republic of China).

Figure 5. China-ASEAN exports growth trend. 
Trade Area has brought trade to China and created the effect. After achieving high growth, China's export growth rate to ASEAN began to decline in 2008 from $32.1 \%$ in 2007 to $21.4 \%$ in 2008 due to the impact of the global economic crisis triggered by the US subprime mortgage crisis. The global economy has been severely affected. China's economy started to decline. The bilateral trade volume has been reduced. As a result, China's exports began to decline. Although the financial crisis started to spread, it still maintained its growth rate of over $20 \%$. However, in 2009, under the constant impact of the financial crisis, bilateral trade was affected by the heavy weight of China's exports to ASEAN. As a result, the export growth rate of China dropped negatively to $-7 \%$.

In 2010, the formal establishment of China-ASEAN Free Trade Area (CAFTA) and the drastic reduction or even reduction of bilateral tariffs to zero have greatly raised bilateral trade volume and boosted the confidence of both parties in free trade, which has led to a rapid growth of China's exports to ASEAN From negative growth in 2009 to positive growth of $30.1 \%$, indicating that the establishment of China-ASEAN Free Trade Area has a positive impact on the development of China's export trade and has played a good leading role. In addition, from 2011 to 2014, China's export to ASEAN declined slightly compared with that in 2010, but both maintained its growth rate above $10 \%$, laying a good trading foundation for the sound development of China and ASEAN in the future.

\subsubsection{Empirical Analysis of Trade Creation Effects through a Gravity Model}

The basic form of trade gravity model is: $T_{i j}=A G_{i} G_{j} / D_{i p}$ where $G_{i}$ and $G_{j}$ represent the economic gross domestic product (GDP) of country $i$ and country $j$ respectively, $D_{i j}$ represents the distance between country $i$ and country $j, T_{i j}$ represents the Trade flows scale, $A$ is constant. In general, in order to facilitate the analysis, we convert the model into a linear logarithmic form and add random error terms. We can get:

$$
\ln T_{i j}=\beta_{0}+\beta_{1} \ln G_{i} G_{j}+\beta_{2} \ln D_{i j}+\mu
$$

where $\beta_{0}$ constant term, $\mu$ is a random error term, the numerical meaning of coefficients $\beta_{1}$ and $\beta_{2}$ represents the elasticity of $T_{i j}$ to $G_{i} G_{j}$ and $D_{i j}$.

Based on the basic framework of gravity model, a dummy variable is introduced to establish the following measurement model:

$$
\ln T_{i j}^{t}=\beta_{0}+\beta_{1} \ln \left(G_{i}^{t} G_{j}^{t}\right)+\beta_{2} \ln D_{i j}+\beta_{3} L_{i j}+\varepsilon_{i j}
$$

Among them, $i$ represents China, $j$ represents trading nation. $T_{i j}^{t}$ represents the bilateral trade volume between China and country $j$ in year $t, G_{i}^{t}$ and $G_{j}^{t}$ respectively represent the gross domestic product of China and country $j$ in year $t$, and $D_{i j}$ represents the distance between China and country $j$, usually using the distance between the two capitals $L_{i j}$ is a virtual variable. When China and $j$ are members of the Free Trade Area in year $t, L_{i j}$ is equal 1, otherwise, equal 0.

This paper chooses China and ASEAN countries (Malaysia, Vietnam, Thail- 
and, Singapore, Indonesia, Philippines, Laos, Brunei and Cambodia) as well as other ten major trade partners of China (the United States, Japan, South Korea, Britain, Germany, Australia, France, Italy, Russia, and Canada), panel data from 2003 to 2014. The bilateral trade volume between China and the trading nation is derived from the UN Commodity Trade Database. The GDP data of all countries come from the UN data center. The distance between China and the capitals of each country originates from Google Earth.

Since the establishment of the China-ASEAN Free Trade Area in 2002 and its successful completion in 2010, this paper sets the 2010 as the critical point when it is enough to construct the econometric model. Since 2010, China and the ASEAN countries established the free trade area, using the above data, the econometric model was estimated by least square method through Eviews 4.1. After heteroscedasticity and autocorrelation test, the following results were obtained:

\begin{tabular}{ccccc}
\hline & $\mathrm{C}$ & $\ln \left(G_{i}^{t} G_{j}^{t}\right)$ & $\ln D_{i j}$ & $L_{i j}$ \\
\hline Coefficient & $-5.23874^{\star * *}$ & $0.824592^{\star * *}$ & $-0.847732^{\star * *}$ & $0.048349^{* * *}$ \\
t-statistics & $(-7.853076)$ & $39.639520)$ & $(-11.3284)$ & $(0.415230)$ \\
Adjusted R & 0.873425 & F-statistic(Prob) & $510.3326(0.000)$ & \\
\hline
\end{tabular}

This data is obtained by OLS regression, ${ }^{* *}$ representing $1 \%$ significance level.

The following regression equation is obtained:

$$
\ln T^{t} i j=-5.23+0.82 \ln \left(G_{i}^{t} G_{j}^{t}\right)-0.85 \ln D_{i j}+0.05 L_{i j}+\varepsilon_{i j}
$$

Through the above empirical regression analysis can be seen that the F-statistic of the model with a probability is 0.00 , it is generally significant and the goodness of fit of the equation is also better. The value of $\beta_{1}$ is 0.82 , and the $\mathrm{t}$-statistics is significant, indicating that bilateral trade will increase by $0.82 \%$ when the bilateral GDP increases by $1 \%$ under other conditions. That is, the development of bilateral trade is affected by the economic development of both sides. The more developed the economy is, the more it will be conducive to the growth of bilateral trade. The value of $\beta_{2}$ is -0.85 , and the t-statistics is significant, indicating that with other conditions unchanged, the bilateral trade volume will decrease by $0.85 \%$ as the distance increases by $1 \%$. That is, the longer the distance between China and the trading nation, the less conducive to the increase of bilateral trade. The value of $\beta_{3}$ is 0.05 and the t-statistics is significant, which means that when the trading nation belongs to China-ASEAN Free Trade Area, the bilateral trade volume will increase by $0.05 \%$, indicating that the establishment of a free trade area has created the trade creation effects and the trade creation value about $0.05 \%$ of the bilateral trade volume.

\subsection{Analysis of the Effect of Trade Transfer}

In 2010, the bilateral tariffs have been drastically reduced after the establishment of the China-ASEAN Free Trade Area, creating favorable conditions for the transfer of trade. At the same time, due to the large differences in the level of 
economic development and advantageous products among the member countries of ASEAN, the import and export of goods from China. Other markets have turned to the ASEAN market to provide good conditions. In many countries that trade with China, there is also a certain gap in the volume of trade. The top five countries or groups in China's import and export trade are selected here because China's trade volume from these regions accounts for the total trade volume of China (More than 50\% in 2012 except for nearly 50\%), so it is mainly based on the changes of the proportion of China's trade volume from these countries or organizations in the 14-year period from 2003 to 2016 to analyze China-ASEAN The trade transfer effect produced by the construction of the trade zone. As shown in Figure 6.

Figure 6 shows that the share of trade between China and ASEAN has generally raised in 2003-2016. Although the share declined in 2008 from $9.3 \%$ in 2007 to $9.0 \%$ in 2008 , the decrease was not significant because of the global financial crisis and the global economic downturn, as well as the corresponding import and export Reduce in 2009 began to rise. After the formal establishment of the free trade zone in 2010, the trade volume between China and ASEAN rebounded and has been steadily rising.

By observing the trend of changes in the import volume of China to the EU, we can see that in the past ten years, the highest level in 2003 was $12.8 \%$, from $12.2 \%$ in 2004 to $10.9 \%$ in 2005, and At the same time, China and ASEAN started to implement their early plans in 2005, which shows that China has shifted from partial import of the EU to ASEAN countries.

The proportion of the total import and export of China and the United States among the five countries or organizations is the highest on average, ranging from $12 \%$ to $15 \%$. However, the overall rate of change shows a decreasing trend, indicating that some of China's exports to the United States Import and export conducted outside the region.

In 2003, China's import and export proportion to Japan was the highest among the five countries or organizations. However, the share of China's exports and

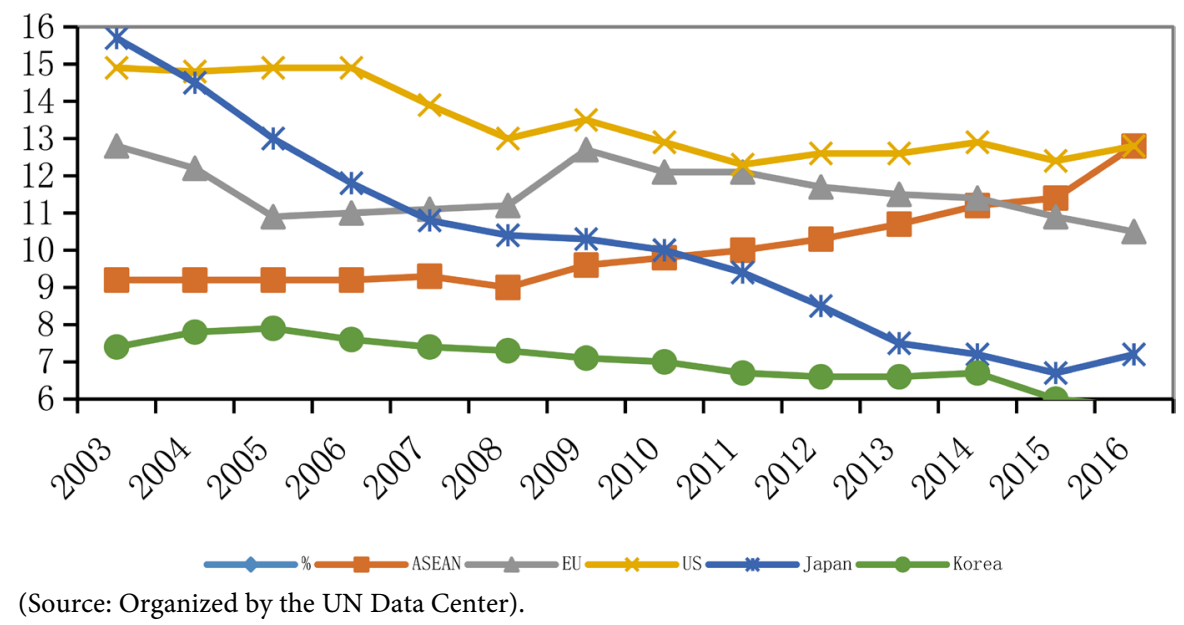

Figure 6. China's trade volume with major trading nations. 
imports to Japan decreased year by year in the next 14 years, with a notable decrease rate from 2003 From $15.7 \%$ in the year to $7.2 \%$ in 2016,we can see that the establishment of China-ASEAN Free Trade Area has a huge effect on the transfer of import and export between China and Japan.

The proportion of China's import and export volume to South Korea is the lowest among the five countries or organizations, with an overall downward trend of between $6 \%$ and $8 \%$. By 2016, the trade share of only $5.8 \%$. This shows that after the establishment of the China-ASEAN Free Trade Area, China's import and export to South Korea has continuously shifted to ASEAN, resulting in some trade transfer effects.

By analyzing the changes in the proportion of China's imports and exports to ASEAN, the EU, Japan, the United States and South Korea, it can be seen that the import share of China and the latter four trade partners in general have shown a marked decrease trend, with the largest change in Japan The proportion of the import and export trade between China and ASEAN tends to increase after 2010, although the increase is modest, but it shows that the establishment of China-ASEAN Free Trade Area has produced the effect of trade transfer. And with the construction and improvement of free trade area, this trade transfer effect will gradually expand.

\section{Policy Recommendations for Promoting the Development of China-ASEAN Free Trade Area}

1) To speed up the upgrading of industrial structure and expand the volume of bilateral trade

From the foregoing, we know that there is competition in the international division of labor between China and ASEAN, mainly because the two sides have great similarities in industrial structure. To this end, China should step up efforts to speed up the upgrading of its industrial structure and achieve trade complementarities to promote long-term economic and trade cooperation in the past two years. First of all, both sides clearly stated that they should play their respective role in the international market, constantly optimize their respective industrial structures, and use the platform of China-ASEAN Free Trade Area to gradually form a relatively close complementary relationship of division of labor. Both sides should make efforts to expand the scope and depth of trade and gradually shift the focus of trade targets from intra-industry trade to intra-industry trade. Second, relying on their respective advantages in resources, factor endowments and location advantages, we should develop industries that have comparative advantages and actively develop the external economy. Thirdly, we should continue to expand the number of bilateral trade in industries with complementary advantages, optimize the tariff system in China-ASEAN free trade zone, gradually liberalize the scope of industries that reduce or exempt tariffs, and gradually expand their respective advantageous industries in trade so as to create a comparative advantage, more complementary industries and fur- 
ther expand the trade effect between the two sides so that both parties can benefit from each other's complementarity.

2) To help countries with backward levels of economic development in ASEAN

If there is a big gap in the economic level among member countries within the FTZ, it will affect the implementation of economic policies among member countries and restrict the development of regional economies. The level of economic development among the ASEAN member states is unbalanced; high-income countries coexist with low-income countries and the income gap within ASEAN is also large. In order for China-ASEAN Free Trade Area to develop healthily, it is necessary for China to help countries with economically underdeveloped conditions.

China can start with the following measures to help ASEAN countries with lower economic development: take the initiative to reduce tariffs. China can take the initiative to reduce tariffs on countries with backward levels of economic development in the Association of Southeast Asian Nations, give preferential policies to countries with poor economic development, such as Myanmar, and promote the development of such countries' trade in goods and economy. Provide financial and technical support to backward countries. China can use domestic funds and rich technology to help these countries carry out technological upgrading while increasing their support for infrastructure construction in these countries, to promote the development of backward industries by industrial transfer, and to promote market diversification and implement product differentiation strategy.

\section{References}

[1] Zhou, Y. (2003) Industrial Relations between China and ASEAN: Competition or Complementarity. Business Economics and Management, No. 7, 56-59.

[2] Shi, Z.Y. (2004) Comparison of Export Similarities between China and ASEAN Countries. Asia-Pacific Economic Forum, No. 2, 84-87 + 76 .

[3] Benjamin, R. (2007) A Gravity Study of the Proposed China-ASEAN Free Trade Area. International Trade Journal, No. 18, 335-353.

[4] Chen, H.-L. and Tu, Y. (2007) An Empirical Analysis of Static Trade Effects of China under the White ASEAN Trade Area of China-ASEAN Based on Gravity Model. International Trade Issues, No. 5, 47-50.

[5] Park, D. (2007) The Prospects of the ASEAN-China Free Trade Area (ACFTA): A Qualitative Overview. Journal of the Asia Pacific Economy, No. 12, 485-503.

[6] Chen, L. and Qu, W.Q. (2012) Analysis of the Trade Effect of China-ASEAN White Paw Trade Area: A Study Based on Heckman's Choice Model. Theory of Theoretical Research, No. 2, 50-57. 